\title{
PENGEMBANGAN MODUL PEMBELAJARAN BERBASIS MULTIKULTUR PADA PENDIDIKAN SEJARAH
}

\author{
Samsidar Tanjung ${ }^{1}$, Naeklan Simbolon ${ }^{2}$, Sugiharto ${ }^{3}$ \\ ${ }^{1,3}$ Fakultas Ilmu Sosial, Universitas Negeri Medan \\ Fakultas Ilmu Pendidikan, Universitas Negeri Medan \\ samsidartanjung@gmail.com
}

\begin{abstract}
Abstrak: Tujuan penelitian adalah: (1) mengembangkan modul berbasis miltikultur pada pendidikan sejarah?; (2) mengetahui apakah modul berbasis multikultur pada pendidikan sejarah layak digunakan dalam proses pembelajaran?; dan (3) mengetahui apakah modul berbasis multikultur pada pendidikan sejarah efektif dapat meningkatkan hasil belajar mahasiswa. Metode penelitian dan pengembangan $R \& D$ dengan mahasiswa pendidikan sejarah FPIS Unimed. Hasil penelitin menunjukkan, bahwa: (1) uji validasi dan uji coba produk pada uji perorangan, kelompok kecil dan lapangan menyatakan bahwa Modul Pendidikan Sejarah sangat bermanfaat untuk digunakan dalam proses pembelajaran; (2) menunjukkan bahwa kualitas pelaksanaan pembelajaran pada uji coba terbatas pada kriteria modul yang dikembangkan sangat baik dan layak digunakan dalam proses pembelajaran dalam pembelajaran pendidikan sejarah. (3) Penilaian Pelaksanaan Pembelajaran dengan Modul Pembelajaran Uji Coba layak digunakan dalam proses pembelajaran Pendidikan Sejarah. (4) penerapan Modul sejarah berbasis berbasis multikultural pada pembelajaran pendidikan sejarah memiliki hasil belajar yang lebih tinggi jika dibandingkan dengan bahan ajar konvensional. (5) Keefektifan Modul sejarah berbasis berbasis multikultural pada pendidikan terhadap hasil belajar digunakan dalam meningkatkan hasil belajar.
\end{abstract}

Kata Kunci: modul pembelajaran, multikultur, pendidikan sejarah

\begin{abstract}
The research objectives are: (1) to develop a milticulture-based module in history education; (2) determine whether the multicultural-based module in history education is suitable for use in the learning process ?; and (3) determine whether the multicultural-based module in history education can effectively improve student learning outcomes. Research and development methods $R \& D$ with history education students FPIS Unimed. The results of the research show that: (1) validation tests and product trials in individual, small group and field trials state that the History Education Module is very useful for use in the learning process; (2) shows that the quality of the implementation of learning in the trial is limited to the criteria for a very well developed modul and is suitable for use in the learning process in learning history education. (3) Assessment of Learning Implementation with Trial Learning Modules suitable for use in the learning process of History Education. (4) the application of a multicultural-based history module to learning history education has higher learning outcomes when compared to conventional teaching materials. (5) The effectiveness of a multicultural-based history module on education on learning outcomes is used in improving learning outcomes.
\end{abstract}

Keywords: learning module, multiculture, historical education

\section{PENDAHULUAN}

Pentingnya perubahan paradigma pendidikan sejarah tersebut bukan semata-mata karena adanya gerakan reformasi yang terjadi belakangan ini, gerakan reformasi itu sendiri hanyalah sebagai faktor pemicu terjadinya gerakan ke arah itu. Robinson (1965) telah merintis perubahan dari Sejarah Lama (The Old History) ke Sejarah Baru (The New History), merupakan reaksi terhadap Sejarah Lama yang terlalu kaku membatasi diri pada sejarah politik. Perluasan pengkajian pada Sejarah Baru mencakup aspek-aspek ekonomi, sosial budaya, pertanian, pendidikan, psiko-logi, teknologi, dan sebagainya secara inter/multidisipliner.
Sejarah Baru ini dengan demikian lebih luas, dan hanya-lah sebagai faktor pemicu terjadinya gerakan ke arah itu. Robinson (1965) telah merintis perubahan dari Sejarah Lama (The Old History) ke Sejarah Baru (The New History), merupakan reaksi terhadap Sejarah Lama yang terlalu kaku membatasi diri pada sejarah politik. Pendidikan diharapkan dapat menghasilkan manusia paripurna yaitu mengembangkan manusia seutuhnya, baik aspek afektif, aspek kognitif, maupun aspek psikomotornya, sehingga peserta didik (mahasiswa) dapat menghadapi berbagai tantangan kehidupan yang dihadapinya. Mendidik adalah menciptakan sistem 
lingkungan yang memungkinkan terjadinya proses belajar. Sistem lingkungan merupakan komponen-komponen yang saling mempengaruhi, yakni tujuan instruksional, materi, dan peran aktif dalam proses pembelajaran. Idochi Anwar (1996:93) menyatakan bahwa kompleksitas pembelajaran dibutuhkan berbagai strategi yang tepat dalam mengelola pembelajaran di kelas. Adapun komponen yang dimaksud adalah: (1) Tujuan pembelajaran ; (2) latar belakang peserta didik; (3) isi dan struktur materi; (4) biaya mengajar; dan (5) fasilitas.

Untuk itulah pendidikan multikulturalisme layak untuk diperkenalkan. Pendidikan multikulturalisme mengemuka sebagai solusi ketidakpuasan masyarakat terhadap sistem pendidikan yang telah dijalankan. Pendidikan multikulturalisme memliki landasan filosofis yakni mengakomodir kesenjangan dalam pendidikan, budaya, dan agama. Ketiga hal tersebut memiliki orientasi yang saling berkaitan yang bermuara pada kemanusiaan. Hal ini selaras dengan salah satu orientasi pendidikan multikultural yakni kemanusiaan.

Pembelajaran berbasis multikultural dengan sistem among yang merdeka belajar didasarkan pada gagasan filosofis tentang kebebasan, keadilan, kesederajatan dan perlindungan terhadap hak-hak manusia. Hakekat pendidikan multikultural mempersiapkan seluruh siswa untuk bekerja secara aktif menuju kesamaan struktur dalam organisasi dan lembaga pendidikan tinggi. Pendidikan multikultural bukanlah kebijakan yang mengarah pada pelembagaan pendidikan dan pengajaran inklusif dan pengajaran oleh propaganda pluralisme lewat kurikulum yang berperan bagi kompetisi budaya individual. Pembelajaran berbasis multikultural berusaha memberdayakan mahasiswa untuk mengembangkan rasa hormat kepada orang yang berbeda budaya, memberi kesempatan untuk bekerja bersama dengan orang atau kelompok orang yang berbeda etnis atau rasnya secara langsung. Pendidikan multikultural juga membantu mahasiswa untuk mengakui ketepatan dari pandangan-pandangan budaya yang beragam, membantu mahasiswa dalam mengembangkan kebanggaan terhadap warisan budaya mereka, menyadarkan mahasiswa bahwa konflik nilai sering menjadi penyebab konflik antar kelompok masyarakat.

\section{Pendidikan Sejarah}

Pembelajaran sejarah yang bersifat eklektik tersebut tidak saja menjadi wahana pengembangan kemampuan intelektual dan kebanggaan masa lampau, tetapi juga merupakan wahana upaya memperbaiki kehidupan masyarakat dalam bidang politik, ekonomi, sosial, budaya. Pembelajaran sejarah juga memiliki nilai praktis-pragmatis bagi mahasiswa, tidak sekedar nilai-nilai teoretikidealisme konseptual. Sebagai konsekuensi logis dari pergeseran filsafat pembelajaran sejarah tersebut, menurut Hasan (1999:9), terdapat tiga hal baru; (1) keterkaitan pelajaran sejarah dengan kehidupan sehari-hari mahasiswa; (2) pemahaman dan kesadaran akan karakteristik cerita sejarah yang tidak bersifat final; dan (3) perluasan tema sejarah politik dengan tema-tema sejarah sosial, budaya, ekonomi, dan teknologi.

Pembelajaran sejarah nasional sebagai unsur pegembangan nasionalisme kultural sangat berfungsi untuk menjadi mediasi dalam memantapkan hubungan antara unsur-unsur masyarakat plural. Anderson (1983:12-16) menyebutkan peran sejarah nasional sebagai identitas nasional dan perkembangan kesadaran nasional. Selanjutnya ia juga melihat arti penting identitas nasional sebagai pengaruh yang paling kuat dan bertahan lama dalam identitas kultural kolektif. Kemudian Vanderburg (1985:272) menambahkan bahwa melalui pembelajaran sejarah nasional, juga berupaya membentuk modul perilaku yang memupuk nasionalisme kultural untuk menciptakan pola hubungan yang mengatasi lingkungan temporal dan spasial serta dimensidimensi lainnya.

Untuk mewujudkan misi pendidikan sejarah berbasis multikultur ini, di kalangan pakar muncul 3 tipologi program pendidikan multikultur yang diintegrasikan ke dalam kurikulum. Ketiga tipologi program tersebut adalah: program yang berorientasi pada konten (content-oriented programs); program yang berorientasi pada peserta didik (student-oriented programs); dan program yang berorientasi sosial (socially-oriented programs). Pakar yang menjadi komponen gerakan baru ini adalah Banks, Sleeter, dan Grant (Gary, 1994). Diskursus akademik ini, menjadi awal munculnya pemikiran tentang pendidikan sejarah berbasis multikultur dan pendidik sebagai intelektual dan pengembang kurikulum multikultur. 


\section{Pendidikan Multikultur}

Istilah multikulturalisme menurut Parekh (1997:2001) sebagaimana dikemukakan oleh Saifuddin (2006:139) mencakup sedikitnya tiga unsur, yaitu (1)terkait dengan kebudayaan, (2) merujuk kepada pluralitas kebudayaan, dan (3)cara tertentu untuk merespon pluralitas tersebut. Dengan demikian, makamultikulturalisme adalah cara pandang kebudayaan yang diwujudkan secara konkret dalam kehidupa yang nyata.

Istilah Pendidikan multikultur dapat digunakan baik pada tataran deskriptif maupun normatif yang menggambarkan isu-isu yang berkaitan dengan masyarakat multikultural. Lebih jauh juga mencakup pengertian tentang pertimbangan terhadap kebijakan-kebijakan dan strategi-strategi pendidikan dalam masyarakat multikultural. Dalam konteks deskriptif, pendidikan multikultural seyogyanya berisi tentang tema-tema tentang toleransi, perbedaan etno-cultural dan agama, bahaya diskriminasi, penyelesaian konflik dan mediasi, hak azasi manusia, pluralitas, kemanusiaan universal, dan subjek-subjek lain yang relevan.1

Pendidikan multikultural dapat dilihat dari 3 (tiga) aspek: konsep, gerakan, dan proses (James A. Bank, 1989: 2-3). Dari aspek konsepnya, pendidikan multikultural dipahami sebagai ide yang memandang semua siswa tanpa memperhatikan gender dan kelas sosial mereka, etnik mereka, ras mereka, dan atau karakteristik-karakteristik kultural lainnya memiliki kesempatan yang sama untuk belajar di kelas. Dari aspek gerakannya, pendidikan multikultural didefinisikan sebagai usaha untuk mengubah sekolah-sekolah dan institusiinstitusi pendidikan sehingga siswa dari semua kelas sosial, gender, ras, dan kelompok-kelompok kultural memiliki kesempatan yang sama untuk belajar. Perubahan yang dilakukan tidak hanya terbatas pada kurikulum, tetapi juga aspek lain seperti metode, strategi, manajemen pembelajaran, dan lingkungan sekolah. Dari aspek prosesnya, pendidikan multikultural dapat dipahami sebagai proses untuk mencapai tujuan agar kesetaraan pendidikan dapat dicapai oleh semua siswa. Kesetaraan pendidikan, seperti kemerdekaan dan keadilan tidak mudah dicapai, karena itu proses ini harus berlangsung terusmenerus.

Pendidikan dalam wawasan multikultural dalam rumusan James A. Bank adalah konsep, ide atau falsafah sebagai suatu rangkaian kepercayaan dan penjelasan yang mengakui dan menilai pentingnya keragaman budaya dan etnis di dalam membentuk gaya hidup, pengalaman sosial, identitas pribadi, kesempatan-kesempatan pendidikan dari individu, kelompok maupun negara. 2

Menurut Sonia Nieto (2002: 29), pendidikan multikultural merupakan proses pendidikan yang komprehensif dan mendasar bagi semua peserta didik. Jenis pendidikan ini menentang segala bentuk rasisme dan segala bentuk diskriminasi di sekolah dan masyarakat dengan menerima dan mengafirmasi pluralitas yang tereflekasikan di antara peserta didik, komunitas mereka dan guru-guru. Menurut Sonia pendidikan multikultur harus melekat dalam kurikulum dan strategi pengajaran, termasuk dalam setiap interaksi yang dilakukan di antara para guru, murid dan keluarga serta keseluruhan suasana belajar mengajar. Jenis pendidikan ini merupakan paedagogi kritis, reflektif dan menjadi basis aksi perubahan dalam masyarakat, maka pendidikan multikultural mengembangkan prinsip-prinsip demokrasi dalam berkeadilan sosial.

Sementara itu Bikhu Parekh (2000: 230) mendefinisikan pendidikan multikultur sebagai "an education in freedom, both in the sense of freedom from ethnocentric prejudices and beases, and freedom to explore and learn from other cultures and perspectives".

Dari uraian di atas ada hal penting dalam diskursus multikultural dalam pendidikan yaitu identitas, keterbukaan, diversitas budaya dan transformasi sosial. Identitas sebagai salah satu elemen dalam pendidikan mengandaikan bahwa peserta didik dan guru merupakan satu individu atau kelompok yang merepresentasikan satu kultur tertentu dalam masyarakat.

Mengenai fokus pendidikan multikultural, Tilaar (2002) mengungkapkan bahwa dalam program pendidikan multikultural, fokus tidak lagi diarahkan semata-mata kepada kelompok sosial, agama, dan kultural mainstream. Pendidikan multikultural sebenarnya merupakan sikap peduli dan mau mengerti ataupun pengakuan terhadap orang lain yang berbeda. Dalam konteks itu, pendidikan multikultural melihat masyarakat secara lebih luas. Berdasarkan pandangan dasar bahwa sikap indeference dan non-recognition tidak hanya berakar dari ketimpangan struktur rasial, tetapi paradigma pendidikan multikultural mencakup subjeksubjek mengenai ketidakadilan, kemiskinan, 
penindasan, dan keterbelakangan kelompokkelompok minoritas dalam berbagai bidang, baik itu sosial, ekonomi, budaya, pendidikan, dan sebagainya (Tilaar, 2002: 15).

Menurut Arifudin (2007) ada beberapa pendekatan dalam proses pendidikan multikultural, antara lain sebagai berikut: Pertama, perubahan paradigm dalam memandang pendidikan (education) dengan persekolahan (schooling) atau pendidikan multikultural dengan program-program sekolah formal. Kedua, menghindari pandangan yang menyamakan kebudayaan dengan kelompok etnik. Dalam konteks pendidikan multikultural, pendekatan ini diharapkan dapat mengilhami para penyusun program pendidikan multikultural untuk menghilangkan kecenderungan memandang peserta didik secara stereotype menurut identitas etnik mereka, dan akan meningkatkan eksplorasi pemahaman yang lebih besar mengenai kesamaan dan perbedaan di kalangan peserta didik dari berbagai suku. Ketiga, karena pengembangan kompetensi dalam kebudayaan baru biasanya membutuhkan interaksi inisiatif dengan orangorang yang sudah memiliki kompetensi, bahkan dapat dilihat lebih jelas bahwa upaya-upaya untuk mendukung sekolah-sekolah yang terpisah secara etnik adalah antithesis terhadap tujuan pendidikan multikultural. Mempertahankan dan memperluas solidaritas kelompok adalah menghambat sosialisasi ke dalam kebudayaan baru. Keempat, pendidikan multikultural meningkatkan kompetensi dalam beberapa kebudayaan. Kelima, pendidikan multikultural baik dalam sekolah maupun luar sekolah meningkatkan kesadaran dalam beberapa kebudayaan. Pendekatan ini meningkatkan kesadaran akan multikulturalisme sebagai pengalaman moral manusia. Kesadaran ini mengandung makna bahwa pendidikan multikultural berpotensi untuk menghindari dikotomi dan mengembangkan apresiasi yang lebih baik melalui kompetensi kebudayaan yang ada pada diri peserta didik.

Pendidikan multikultural didasari pada asumsi bahwa setiap manusia memiliki identitas, sejarah, lingkungan, dan pengalaman hidup yang berbeda-beda. Perbedaan adalah identitas terpenting dan paling otentik tiap manusia dari kesamaannya. Kegiatan belajar mengajar bukan ditujukan agar peserta didik menguasai sebanyak mungkin materi ilmu, tetapi bagaimana tiap peserta didik mengalami sendiri proses berilmu dan hidup di ruang kelas dan lingkungan pendidikan.

Dalam hal ini guru atau tenaga pendidik, tidak lagi ditempatkan sebagai actor tunggal dan terpenting dalam proses pembelajaran yang serba tahu dan serba bisa. Tapi pendidik yang efisien dan produktif adalah yang bisa menciptakan situasi sehingga peserta didik belajar dengan cara yang unik. Kelas diciptakan bukan untuk mengubur identitas personal, tetapi memperbesar peluang tiap peserta didik mengaktualkan kedirian masingmasing.

Menurut Tatang M. Amirin (2012: 6), dalam konteks Indonesia, implementasi pendidikan multikultural dapat dilihat pada:

a. Falsafah pendidikan, yaitu pandangan bahwa kekayaan keragaman budaya Indonesia hendaknya dimanfaatkan sebaik-baiknya untuk mengembangkan dan meningkatkan system pendidikan dan kegiatan belajar mengajar guna mencapai masyarakat Indonesia yang adil dan makmur bahagia dunia akherat.

b. Sebagai pendekatan pendidikan, yaitu penyelenggaraan dan pelaksanaan pendidikan yang kontekstual, yang memperhatikan keragaman budaya Indonesia. Nilai budaya diyakini mempengaruhi pandangan, keyakinan, dan perilaku individu (pendidik dan peserta didik) dan akan terbawa ke dalam situasi pendidikan di sekolah dan pergaulan informal antar individu, serta mempengaruhi pula struktur pendidikan di sekolah (kurikulum, dan faktor lainnya)

c. Bidang kajian dan bidang studi; yaitu disiplin ilmu yang menelaah dan mengkaji aspekaspek kebudayaan, terutama nilai-nilai budaya dan perwujudannya, dalam penyelenggaraan dan pelaksanaan pendidikan. Hasil telaah dan kajian ini akan dapat menjadi bidang studi yang diajarkan secara operasional dan kontekstual kepada para peserta didik yang akan berhadapan dengan keragaman budaya.

Selanjutnya James Banks, dalam Muhaemin el-Ma'hady, menjelaskan bahwa pendidikan multikultural memiliki lima dimensi yang saling berkaitan: (1) Content integration, mengintegrasikan berbagai budaya dan kelompok untuk mengilustrasikan konsep mendasar, generalisasi dan teori dalam mata pelajaran/ disiplin ilmu; (2) The Knowledge Construction Process, membawa siswa utuk 
memahami impliksi budaya ke dalam sebuah mata pelajaran (disiplin); (3) An Equity Pedagogy, menyesuaikan metode pengajaran dengan cara belajar siswa dalam rangka memfasilitasi prestasi siswa yang beragam baik dari segi ras, budaya ataupun sosial; (4) Prejudice Reduction, mengidentifikasi karakteristik ras siswa dan menentukan metode pengajaran mereka; (5) Melatih kelompok untuk berprestasi dalam kegiatan olehraga, berinteraksi dengan seluruh staff dan siswa berbeda etnis dan ras dalam upaya menciptakan akademik.

Tujuan menurut Saudi Patro. (1997: 116) program pendidikan multikultural adalah untuk membantu siswa: (1) Memahami latar belakang diri dan kelompok dalam masyarakat, (2) Menghormati dan mengapresiasi kebhinekaan budaya dan sosio-historis etnik, (3) Menyelesaikan sikap-sikap yang terlalu etnosentris dan penuh purbasangka, (4) Memahami faktor-faktor sosial, ekonomis, psikologis, dan historis yang menyebabkan terjadinya polarisasi etnik ketimpangan dan keterasingan etnik (5) Meningkatkan kemampuan menganalisis secara kritis masalahmasalah rutin dan isu melalui proses demokratis melalui sebuah visi tentang masyarakat yang lebih baik, adil dan bebas dan (6) Mengembangkan jati diri yang bermakna bagi semua orang.

Rumusan masalah penelitian adalah: (1) bagaimana mengembangkan modul berbasis miltikultur pada pendidikan sejarah?; (2) apakah modul berbasis multikultur pada pendidikan sejarah layak digunkan dalam proses pembelajaran?; dan (3) apakah modul berbasis multikultur pada pendidikan sejarah efektif dapat meningkatkan hasil belajar mahasiswa?

\section{METODE}

Model penelitian pengembangan menurut Borg \& Gall (2003: 271) memiliki sepuluh tahap. Adapun kesepuluh tahapan tersebut adalah: (1) Penelitian dan pengumpulan informasi awal (research and information collection). (2) Perencanaan (planning); (3) Pengembangan format produk awal (develop preliminary form of product) (4) Uji coba awal (preliminary field testing); (5) Uji coba lapangan (main field testing); Revisi produk utama dilakukan berdasarkan hasil uji coba produk tahap pertama. (6) Uji coba lapangan (operational field testing); Pengujian produk di lapangan disarankan mengambil sampel yang lebih banyak yaitu 30-100 orang responden (5-15 sekolah). (7) Revisi produk (operational produk revision); (8) Uji lapangan (operational field testing); (9) Revisi produk akhir (Final product revision); (10) Desiminasi dan implementasi (Desimination and implementation).

Model penelitian Borg \& Gall dalam pengembangan komik perlu diadakan uji validasi sebelum kemudian produk diuji coba ke lapangan. Uji validasi ini dilakukan oleh validator yang memiliki latar belakang yang baik dalam menguji kelayakan dari produk yang akan dikembangkan.

Penelitian ini merupakan penelitian dan pengembangan (Research \& Development), Penelitian dan pengembangan ini terdiri dari tiga tahap yaitu pra pengembangan modul, pengembangan modul dan penerapan modul dimana penelitian mengacu pada model $4 D$. yang meliputi tahap pendefinisian (define), perancangan (design), pengembangan (develop), serta tahap pendeseminasian (disseminate). Kerangka penelitian secara garis besar di tata dengan urutan sebagai berikut: mengumpulkan data kondisi saat ini untuk diagnosa kebutuhan, analisis data, mengembangkan, memilih alternatif tindakan, uji coba modul baru, memeriksa reaksi, mengumpulkan data baru untuk diagnosa, mengulangi analisis pengembangan, dan merevisi modul. Metode yang digunakan dalam penelitian ini adalah gabungan metode kualitatif dan kuantitatif (mixed method).

Penelitian dilakukan di Program Studi Pendidikan Sejarah, FIS UNIMED pada matakuliah pendidikan sejarah Tahun Akademik 2020/2021. Baik validasi ahli, uji coba perorangan, ujicoba kelompok kecil, dan ujicoba utama dilakukan di Unimed. Subjek penelitian adalah mahasiswa dan dosen. Pada tahap pengembangan modul pembelajaran, penentuan sasaran dalam hal ini adalah dosen, pakar pembelajaran, ahli bidang studi, dan mahasiswa yang menilai modul pembelajaran yang telah dikembangkan berdasarkan kriteria, sebagai berikut: (1) evaluasi pakar pembelajaran (expert judgement) ditentukan berdasarkan kepakaran yang dimilikinya, (2) evaluator yang melaksanakan evaluasi ditentukan berdasarkan pada kemampuan dosen dengan klasifikasi ahli bidang studi.

Pengumpulan data dalam penelitian dan pengembangan ini dikelompokkan menjadi tiga, 
yaitu studi pendahuluan, pengembangan, dan uji validasi. Dalam setiap tahap penelitian dipilih teknik pengumpulan data tertentu sesuai dengan tujuan masing-masing. Pada studi pendahuluan, dipilih teknik kuesioner/angket, observasi, dan dokumentasi, di samping kajian literatur (literature review). Secara umum, ketiga, teknik tersebut digunakan secara bersamaan dan saling melengkapi.

Teknik analisis data dalam penelitian dan pengembangan ini menggunakan analisis deskriptif kualitatif dan kuantitatif. Semua data yang terkumpul dianalisis dengan teknik statistik deskriptif yang secara kuantitatif dipisahkan menurut kategori untuk mempertajam penilaian dalam menarik kesimpulan, reduksi data, display data pengambilan keputusan dan verifikasi. Analisis data dalam penelitian dan pengembangan ini dijelaskan dalam tiga, yaitu tahap studi pendahuluan, pengembangan dan validasi. Pada tahap validasi, keberartian dan efektivitas hasil penerapan modul dianalisis menggunakan pendekatan kuantitatif (quasi exsperimental), dengan membandingkan hasil pada kelompok (subjek penelitian) eksperimen dan kelompok kontrol, pada kondisi sebelum dengan sesudah penerapan. Anaisis kuantitatif melalui ujicoba dengan teknik pretest-postest dan analisis uji-t.

\section{HASIL PENELITIAN}

Hasil Validasi/Uji Ahli Modul Pembelajaran

Validasi modul pembelajaran ini merupakan proses kegiatan untuk menilai apakah rancangan produk berupa modul pembelajaran yang akan digunakan sebagai sumber belajar dalam proses pembelajaran, akan lebih efektif. Hal ini dilakukan, sebelum perangkat pembelajaran ini digunakan dalam proses pembelajaran berlangsung.

Modul sejarah berbasis berbasis multikultural ini dilakukan validasi terlebih dahulu oleh dua orang pakar/ahli bidang studi. Setiap ahli/pakar diminta untuk menilai kelayakan modul pembelajaran yang dikembangkan, sehingga dapat diketahui kelemahan dan kekuatannya. Validasi modul pembelajaran ini setelah dilakukan penilaian terhadap komponen kelayakan, selanjutnya dilakukan revisi/perbaikan. Hasil dari revisian/perbaikan modul dikembangkan lagi untuk dijadikan modul yang siap digunakan oleh mahasiswa dalam proses pembelajaran. Modul pembelajaran yang dikembangkan ini diorganisir terhadap penataan isi materi modul, sehingga dapat memudahkan mahasiswa belajar.

Tabel 1. Penilaian Ahli Media Pembelajaran pada modul sejarah berbasis berbasis multikultural

\begin{tabular}{|c|l|c|c|}
\hline No. & \multicolumn{1}{|c|}{$85,67 \mathrm{r}$} & $\%$ & Kriteria \\
\hline 1. & Ukuran Modul & & \\
\hline & a. Kesesuaian ukuran modul dengan standar ISO & 86,5 & SB \\
\hline & b. Kesesuaian ukuran dengan materi isi modul & 85.0 & SB \\
\hline 2. & Desain Sampul Modul (Cover) & & \\
\hline & $\begin{array}{l}\text { a. Penampilan unsur tata letak pada sampul muka, belakang dan } \\
\text { punggung secara harmonis memiliki irama dan kesatuan (unity) } \\
\text { serta konsisten }\end{array}$ & 65.5 & B \\
\hline b. Menampilkan pusat pandang (center point) yang baik. & 68.5 & B \\
\hline $\begin{array}{l}\text { c. Komposisi dan ukuran unsur tata letak (judul, pengarang, } \\
\text { ilustrasi, logo, dll) proporsional, seimbang dan seirama dengan } \\
\text { tata letak isi (sesuai pola). }\end{array}$ & $\begin{array}{l}\text { d. Warna unsur tata letak harmonis dan memperjelas fungsi } \\
\text { dibandingkan ukuran buku, nama pengarang }\end{array}$ & 75.5 & B \\
\hline & $\begin{array}{l}\text { f. Warna judul buku kontras dengan warna latar belakang } \\
\text { g. Tidak menggunakan terlalu banyak kombinasi jenis huruf }\end{array}$ & 80.5 & SB \\
\hline & $\begin{array}{l}\text { h. Menggambarkan isi/ materi ajar dan mengungkapkan karakter } \\
\text { objek }\end{array}$ & 84.5 & SB \\
\hline & i. Bentuk, warna, ukuran, proporsi obyek sesuai dengan realita. \\
\hline 3. & Desain Isi Modul: & 80.0 & SB \\
\hline & a. Penempatan unsur tata letak konsisten berdasarkan pola & 80.5 & SB \\
\hline & b. Pemisahan antar paragraf jelas & 88.5 & SB \\
\hline
\end{tabular}




\begin{tabular}{|l|l|c|c|}
\hline No. & \multicolumn{1}{|c|}{$85,67 \mathrm{r}$} & $\%$ & Kriteria \\
\hline & \multicolumn{1}{|c|}{ c. Bidang cetak dan margin proporsional } & 78.5 & $\mathrm{~B}$ \\
\hline & d. Marjin dua halaman yang berdampingan proporsional & 80.5 & SB \\
\hline & $\begin{array}{l}\text { e. Spasi antara teks dan ilustrasi sesuai } \\
\text { f. Penempatan judul kegiatan belajar, sub judul kegiatan belajar, dan } \\
\text { angka halaman/ folio tidak mengganggu pemahaman }\end{array}$ & 87.0 & SB \\
\hline $\begin{array}{l}\text { g. Penempatan ilustrasi dan keterangan gambar (caption) tidak } \\
\text { mengganggu pemahaman }\end{array}$ & $\begin{array}{l}\text { SB } \\
\begin{array}{l}\text { h. Penempatan hiasan/ ilustrasi sebagai latar belakang tidak } \\
\text { mengganggu judul, teks, angka halaman }\end{array}\end{array}$ & B \\
\hline $\begin{array}{l}\text { i. Penempatan judul, subjudul, ilustrasi, dan keterangan gambar } \\
\text { tidak mengganggu pemahaman }\end{array}$ & 80.5 & SB \\
\hline j. Tidak menggunakan terlalu banyak jenis huruf & 78.5 & B \\
\hline $\begin{array}{l}\text { k. Penggunaan variasi huruf (bold, italic, all capital, small capital) } \\
\text { tidak berlebihan }\end{array}$ & 80.5 & SB \\
\hline l. Lebar susunan teks normal & 76.5 & B \\
\hline m. Spasi antar baris susunan teks normal & 80.5 & SB \\
\hline n. Spasi antar huruf (kerning) normal & 86.5 & SB \\
\hline o. Jenjang/ hierarki judul-judul jelas, konsisten dan proporsional & 82.5 & SB \\
\hline p. Tanda pemotongan kata (hyphenation) & 68.0 & B \\
\hline q. Ilustrasi isi mampu mengungkap makna/ arti dari objek & 80.5 & SB \\
\hline r. Bentuk akurat dan proporsional sesuai dengan kenyataan & 79.5 & B \\
\hline s. Ilustrasi isi penyajian keseluruhan serasi & 76.5 & B \\
\hline t. Kreatif dan dinamis ilustrasi isi & 78.5 & B \\
\hline
\end{tabular}

Keterangan: $\mathrm{B}=$ Baik dan $\mathrm{SB}=$ Sangat Baik

Tabel 2. Penilaian Ahli Materi Pembelajaran pada modul sejarah berbasis berbasis multikultural

\begin{tabular}{|c|l|c|c|}
\hline No. & \multicolumn{1}{|c|}{ Indikator } & $\%$ & Kriteria \\
\hline 1 & Aspek Kelayakan Isi: & & \\
\hline & a. Kelengkapan materi sesuai Capaian Pembelajaran & 85.0 & SB \\
\hline b. Keluasan materi & & \\
\hline c. Kedalaman materi & 75.5 & B \\
\hline d. Keakuratan konsep dan definisi & 78.5 & B \\
\hline e. Keakuratan data dan fakta & 85.0 & SB \\
\hline f. Keakuratan contoh dan kasus & 85.0 & SB \\
\hline g. Keakuratan gambar, diagram, dan ilustrasi & 84.5 & SB \\
\hline h. Keakuratan istilah-istilah & 80.5 & SB \\
\hline i. Keakuratan notasi, simbol, dan ikon & 82.5 & SB \\
\hline j. Keakuratan acuan pustaka & 84.5 & SB \\
\hline k. Kesesuaian materi & 85.0 & SB \\
\hline l. Contoh dan kasus dalam & & \\
\hline m. Gambar, diagram dan ilustrasi & 65.5 & B \\
\hline n. Kemutahiran pustaka & 68.5 & B \\
\hline o. Mendorong rasa ingin tahu & 84.5 & SB \\
\hline p. Menciptakan kemampuan bertanya & 85.0 & SB \\
\hline Aspek Penyajian: & 75.5 & B \\
\hline a. Konsistensi sistematika sajian dalam kegiatan belajar & 84.5 & SB \\
\hline b. Keruntutan konsep penyajiannya & 85.0 & SB \\
\hline c. Contoh-contoh soal dalam setiap kegiatan belajar mendukung \\
penyajian & 65.5 & B \\
\hline d. Soal latihan pada setiap akhir kegiatan belajar & 68.5 & B \\
\hline e. Kunci jawaban soal latihan & 75.5 & B \\
\hline f. Pengantar glosarium & 80.5 & SB \\
\hline
\end{tabular}




\begin{tabular}{|c|c|c|c|}
\hline No. & Indikator & $\%$ & Kriteria \\
\hline \multirow[t]{17}{*}{1} & Aspek Kelayakan Isi: & & \\
\hline & a. Kelengkapan materi sesuai Capaian Pembelajaran & 85.0 & SB \\
\hline & b. Keluasan materi & & \\
\hline & c. Kedalaman materi & 75.5 & $\mathrm{~B}$ \\
\hline & d. Keakuratan konsep dan definisi & 78.5 & B \\
\hline & e. Keakuratan data dan fakta & 85.0 & SB \\
\hline & f. Keakuratan contoh dan kasus & 85.0 & SB \\
\hline & g. Keakuratan gambar, diagram, dan ilustrasi & 84.5 & SB \\
\hline & h. Keakuratan istilah-istilah & 80.5 & SB \\
\hline & i. Keakuratan notasi, simbol, dan ikon & 82.5 & SB \\
\hline & j. Keakuratan acuan pustaka & 84.5 & SB \\
\hline & k. Kesesuaian materi & 85.0 & SB \\
\hline & 1. Contoh dan kasus dalam & & \\
\hline & m. Gambar, diagram dan ilustrasi & 65.5 & B \\
\hline & n. Kemutahiran pustaka & 68.5 & B \\
\hline & o. Mendorong rasa ingin tahu & 84.5 & SB \\
\hline & p. Menciptakan kemampuan bertanya & 85.0 & SB \\
\hline \multirow[t]{9}{*}{2} & Aspek Penyajian: & 75.5 & $\mathrm{~B}$ \\
\hline & a. Konsistensi sistematika sajian dalam kegiatan belajar & 84.5 & SB \\
\hline & b. Keruntutan konsep penyajiannya & 85.0 & SB \\
\hline & $\begin{array}{l}\text { c. Contoh-contoh soal dalam setiap kegiatan belajar mendukung } \\
\text { penyajian }\end{array}$ & 65.5 & B \\
\hline & g. Daftar pustaka & 75.5 & $\mathrm{~B}$ \\
\hline & h. Rangkuman & 80.5 & SB \\
\hline & i. Keterlibatan mahasiswa dalam penyajian pembelajaran & 82.5 & SB \\
\hline & j. Ketertautan antar kegiatan belajar/sub kegiatan & 84.5 & SB \\
\hline & k. belajar/alenia secara runtut alur pikirnya & 80.0 & SB \\
\hline \multirow[t]{7}{*}{3} & Penilaian Bahasa: & & \\
\hline & a. Lugas & 80.5 & SB \\
\hline & b. Komunikatif & 88.5 & SB \\
\hline & c. Dialogis dan interaktif & 65.5 & $\mathrm{~B}$ \\
\hline & d. Kesesuaian dengan tingkat perkembangan belajar & 68.5 & $\mathrm{~B}$ \\
\hline & e. Keruntutan dan ketepatan alur pikir & 75.5 & $\mathrm{~B}$ \\
\hline & f. Penggunaan istilah, simbol atau ikon & 80.5 & SB \\
\hline
\end{tabular}

Keterangan: $\mathrm{B}=$ Baik dan SB = Sangat Baik

Tabel 3. Respon Mahasiswa terhadap modul sejarah berbasis berbasis multikultural

\begin{tabular}{|c|l|c|c|}
\hline No. & \multicolumn{1}{|c|}{ Indikator } & \% & Kriteria \\
\hline 1 & Aspek Tampilan: & & \\
\hline & $\begin{array}{l}\text { a. Teks atau tulisan pada modul ini mudah dibaca. } \\
\text { b. Gambar yang disajikan jelas atau tidak buram. }\end{array}$ & 86,72 & SB \\
\hline $\begin{array}{l}\text { c. Gambar yang disajikan sudah sesuai (tidak terlalu banyak dan } \\
\text { tidak terlalu sedikit) }\end{array}$ & 85.43 & SB \\
\hline $\begin{array}{l}\text { d. Adanya keterangan pada setiap gambar yang disajikan dalam } \\
\text { modul ini. }\end{array}$ & 65.62 & B \\
\hline 2 & $\begin{array}{l}\text { e. Gambar yang disajikan menarik. } \\
\text { f. Gambar yang disajikan sesuai dengan materi }\end{array}$ & 68.83 & B \\
\hline $\begin{array}{l}\text { a. Modul ini menjelaskan suatu konsep menggunakan ilustrasi } \\
\text { masalah yang berkaitan }\end{array}$ & 75.94 & B \\
\hline $\begin{array}{l}\text { b. Modul ini menggunakan contoh-contoh soal yang berkaitan } \\
\text { dengan masalah }\end{array}$ & 80.15 & SB \\
\hline
\end{tabular}




\begin{tabular}{|l|l|c|c|}
\hline & $\begin{array}{l}\text { c. Penyajian materi dalam modul ini mendorong saya untuk } \\
\text { berdiskusi dengan teman-teman yang lain. }\end{array}$ & 82.44 & SB \\
\hline $\begin{array}{l}\text { d. Penyajian materi dalam modul ini berkaitan dengan materi } \\
\text { matematika yang lain atau dengan mata pelajaran yang lain dalam } \\
\text { pemecahan masalah dan penerapannya. }\end{array}$ & 84.64 & SB \\
\hline & e. Saya dapat memahami materi dengan mudah. & 80.3 & SB \\
\hline f. Materi yang disajikan dalam modul sudah runtut. & $\begin{array}{l}\text { g. Saya dapat mengikuti kegiatan belajar tahap demi tahap dengan } \\
\text { mudah. }\end{array}$ & 80.26 & SB \\
\hline $\begin{array}{l}\text { h. Saya dapat dengan mudah memahami kalimat yang digunakan } \\
\text { dalam modul ini. }\end{array}$ & 88.63 & SB \\
\hline $\begin{array}{l}\text { i. Tidak ada kalimat yang menimbulkan makna ganda dalam modul } \\
\text { ini. }\end{array}$ & 78.64 & B \\
\hline $\begin{array}{l}\text { j. Saya dapat memahami pada modul ini. } \\
\text { k. Saya dapat memahami istilah-istilah yang digunakan dalam } \\
\text { modul ini. }\end{array}$ & 87.06 & SB \\
\hline $\begin{array}{l}\text { l. } \text { Contoh soal yang digunakan dalam modul ini sudah sesuai } \\
\text { dengan materi. }\end{array}$ & 88.54 & SB \\
\hline Aspek Manfaat: & $\begin{array}{l}\text { a. Saya dapat memahami materi menggunakan modul ini dengan } \\
\text { mudah }\end{array}$ & 77.31 & B \\
\hline $\begin{array}{l}\text { b. Saya merasa lebih mudah belajar dengan menggunakan modul } \\
\text { ini }\end{array}$ & 80.44 & SB \\
\hline c. Saya sangat tertarik menggunakan modul ini. & 78.65 & B \\
\hline d. Dengan menggunakan modul ini saya lebih tertarik dalam belajar. & 80.74 & SB \\
\hline $\begin{array}{l}\text { e. Dengan adanya ilustrasi disetiap awal materi dapat memberikan } \\
\text { motivasi untuk mempelajari materi. }\end{array}$ & 76.32 & B \\
\hline f. Saya lebih rajin belajar dengan menggunakan modul ini & 80.23 & SB \\
\hline
\end{tabular}

Keterangan: B = Baik dan SB = Sangat Baik

Uji operasional yang dilakukan secara bersiklus melalui empat tahapan utama, yaitu perencanaan, pelaksanaan, observasi, dan refleksi. Uji operasional lebih bersifat perbaikan terhadap modul sebelum dilakukan uji eksperimen. Dalam uji operasional ini terdiri dari dua siklus. Dalam setiap siklus terdiri dari tiga tindakan dan satu pertemuan untuk evaluasi. Data pada setiap siklus diambil menggunakan lembar observasi terhadap unjuk kerja dan hasil kerja selama proses pembelajaran. Item penilaian atau pengamatan dikembangkan berdasarkan indikator-indikator dalam menggunakan alat dan bahan.

Penelitian dan pengembangan pada tahap pertama ini telah dilakukan: (1) analisis kebutuhan terhadap modul sejarah berbasis berbasis multikultural, (2) kebutuhan terhadap pengembangan modul pembelajaran berbasis multikultural, (3) perencanaan/penyusunan dan pengembangan modul sejarah berbasis berbasis multikultural meliputi; merumuskan tujuan pembelajaran, menganalisis kendala dan karakteristik bidang studi, menyusun silabus dan rencana pelaksanaan semester (RPS), menganalisis karakteristik mahasiswa, merumuskan strategi pembelajaran meliputi; kegiatan pra pembelajaran, penyajian informasi, peran serta mahasiswa, pemberian tes, dan kegiatan tindak lanjut, merancang kebutuhan waktu dan sumber belajar, merancang alat evaluasi, (2) pelaksanaan pembelajaran, dan (3) evaluasi pembelajaran. Hasil temuan ini akan menjadi bahan pada tahap kedua.

Hasil temuan pada tahap pertama ini adalah: (1) modul sejarah berbasis berbasis multikultural yang cocok dan tepat yang akan dikembangkan dan media pembelajaran yang dapat memberi kemudahan belajar mahasiswa, (2) menemukan kompetensi yang harus dimiliki oleh lulusan sesuai pasar kerja, (3) menemukan materi kompetensi perencanaan pembelajaran, (4) menemukan strategi pembelajaran dengan modul sejarah berbasis berbasis multikultural bagi mahasiswa, (5) mengembangkan modul pembelajaran berbasis 
multikultural, (6) menemukan pola manajemen pembelajaran yang mendukung peningkatan kompetensi mahasiswa.

Rencana tahap kedua (II) adalah Melakukan kajian terhadap modul sejarah berbasis berbasis multikultural yang dikembangkan, kompetensi dan materi pembelajaran yang telah ditemukan pada tahap pertama. Modul sejarah berbasis berbasis multikultural pada mahasiswa dilakukan uji coba dan validasi ahli/pakar di bidangnya. Dengan demikian tahap kedua ini akan dilakukan validasi, dan uji coba modul pembelajaran.

Penelitian pada tahap selanjutnya yaitu tahap II, diharapkan akan dapat menghasilkan dan mengembangkan modul sejarah berbasis berbasis multikultural . Modul sejarah berbasis berbasis multikultural mampu memberikan pola strategi pembelajaran yang berbeda sesuai dengan tingkat dan perkembangan kognitif mahasiswa, serta penggunaan teknologi yang menyertai dalam proses pembelajaran berlangsung. Kemampuan ditekankan pada kemampuan tingkat tinggi, yaitu pada C4 sampai dengan C6 sesuai dengan kemampuan kognitif mahasiswa dalam upaya meningkatkan penguasaan terhadap matakuliah sejarah. Melalui serangkaian tahap pengembangan dan validasi ahli serta uji coba pada tahap II akan dapat menghasilkan modul yang utuh dan yang dapat digunakan dalam pengembangan proses pembelajaran dengan baik pada mahasiswa.

Uji coba modul dilakukan dalam tahap kedua ini melalui uji coba perseorangan, uji coba kelompok kecil, dan uji coba lapangan dengan beberapa mahasiswa, disamping itu juga dilakukan uji ahli terhadap bidang studi, ahli rancangan pembelajaran. Dari hasil uji coba diharapkan diperoleh masukan sebagai bahan penyempurnaan draft modul yang diuji cobakan. Hasil kajian pada tahap kedua ini adalah desain modul sejarah berbasis berbasis multikultural pada mahasiswa. Hasil uji coba dan validasi dari ahli untuk selanjutnya dilakukan revisi pada masing-masing aspek dan komponen modul sejarah berbasis berbasis multikultural untuk penyempurnaan modul pembelajaran yang dikembangkan. Pada tahap ke dua ini juga dilakukan uji coba melalui: review ahli bidang studi, review ahli design pembelajaran, uji coba perorangan, uji coba kelompok kecil, dan uji coba lapangan/utama.
Rencana tahap kedua (II) adalah melakukan kajian terhadap:

(1) validasi ahli pada meteri pembelajaran modul sejarah berbasis berbasis multikultural . Validasi dilakukan oleh dua orang ahli di bidang Desain Sistem Instruksional

(2) validasi ahli pada desain grafis; Validasi desain grafis dilakukan oleh dua orang ahli di bidang desain grafis

(3) validasi ahli bidang desain instruksional. Validasi ahli desain instruksional oleh dua orang ahli di bidangnya

Masing-masing ahli yang ditunjuk dalam melakukan review terhadap produk pengembangan pada pengembangan modul sejarah berbasis berbasis multikultural maupun terhadap modul Pembelajaran Sejarah berbasis multikultural.

Selanjutnya dilakukan tahapan uji coba terhadap sararan penelitian pada dosen dan mahasiswa, dengan rahaan sebagai berikut:

(1) Uji coba perorangan; Uji coba perorangan dilakukan untuk mengetahui kualitas dari produk yang akan dihasilkan yaitu pada modul sejarah berbasis berbasis multikultural dan modul pembelajaran. Ketercapaian produk pada sasaran yaitu mahasiswa yang akan menggunakan, terlebih dahulu dilihat tingkat keterbacaan pemahaman materi, keterjelasan sajian materi, kelayakan materi untuk digunakan pada jenjang yang telah ditentukan, kemenarikan sajian produk yang dihasilkan. Uji coba perongan dilakukan pada responden sebanyak 3-5 orang dengan kemampuan dan karakteristik yang berbeda-beda. Dapat diguanakan responden melalui teman sejawat dan mahasiswa secara langsung. Kriteria mahasiswa yang dilibatkan adalah mahasiswa yang memunyai prestasi akademik endah, prestasi akademik sedang, dan prestasi akademik tinggi terhadap penguasaan atau kemampuan terhadap mata kuliah perencanaan pembelajaran yang telah diambilnya.

(2) Uji coba kelompok kecil kepada mahasiswa; Uji coba kelompok kecil dilakukan pada mahasiswa yang bukan dari uji coba utama nanti dilakukan. Uji coba kelompok kecil diberikan pada 9-12 orang mahasiswa dengan melakukan pengkajian terhadap produk yang dilasilkan melalui beberapa tahapan yang harus mereka berikan 
masukan, yaitu aspek kemenarikan, aspek pengetahuan, aspek kemenarikan, aspek keterbacaan, dan

(3) Uji coba utama atau lapangan pada seluruh kelas yang mengambil mata kuliah perencanaan pembelajaran. Uji coba utama atau lapangan dilakukan untuk satu kelas maupun dua kelas sekaligus. Uji coba utama dapat dilakukan melalui perguruan tinggi lainnya yang ada mata kuliah perencanaan pembelajaran. Uji coba ini secara langsung dapat membuktikan bahwa penggunaan modul sejarah berbasis berbasis multikultural dapat dilakukan dengan baik atau tidak. Penguasaan dan penerapan modul sejarah berbasis berbasis multikultural benar-benar diberikan untuk beberapa kali pertemuan sesuai dengan tahapan dan alokasi waktu yang disediakan. Melalui uji coba lapangan ini akan dilakukan uji efektifitas produk yang dihasilkan. Ada dua produk yang dihasilkan dalam pengembangan ini yaitu modul sejarah berbasis berbasis multikultural. Disamping perangkat assessment lain maupun alat evaluasi lain yang digunakan dalam pelaksanaan dan pengembangan modul dilakukan.

Untuk mengetahui kualitas pembelajaran dengan menggunakan modul sejarah berbasis berbasis multikultural dilakukan implementasi penerapan modul pembelajaran dengan menggunakan modul pembelajaran berbasis multikultural. Tujuan penggunaan modul sejarah berbasis berbasis multikultural pada matakuliah perencanaan pembelajaran untuk meningkatkan kualitas pembelajaran dan karakter mahasiswa yang dikembangkan, kompetensi dan materi pembelajaran yang telah ditemukan pada tahap pertama.

Uji coba modul sejarah berbasis berbasis multikultural dilakukan dalam tahap kedua ini melalui uji coba perseorangan, uji coba kelompok kecil, dan uji coba lapangan dengan beberapa mahasiswa, disamping itu juga dilakukan uji ahli terhadap bidang studi, ahli rancangan pembelajaran. Dari hasil uji coba diharapkan diperoleh masukan sebagai bahan penyempurnaan draft modul yang diuji cobakan. Hasil kajian pada tahap kedua ini adalah modul sejarah berbasis berbasis multikultural untuk meningkatkan kualitas pembelajaran dan karakter mahasiswa.

Hasil uji coba dan validasi dari ahli untuk selanjutnya dilakukan revisi pada masing-masing aspek dan komponen pembelajaran berkarakter dan konstruktivistik untuk penyempurnaan modul pembelajaran yang dikembangkan.

Uji operasional dilakukan secara siklus melalui empat tahapan utama, yaitu perencanaan, pelaksanaan, pengamatan, dan refleksi. Uji operasional lebih merupakan perbaikan modul sebelum dilakukan uji eksperimental. Dalam uji operasional ini terdiri dari dua siklus. Setiap siklus terdiri dari tiga tindakan dan satu pertemuan untuk evaluasi. Data pada setiap siklus diambil dengan menggunakan lembar observasi kinerja dan hasil kerja selama proses pembelajaran. Item penilaian atau observasi dikembangkan berdasarkan indikator dengan menggunakan alat dan bahan. Berdasarkan data hasil analisis pada Tabel 2 dapat disimpulkan bahwa siklus 1 dan siklus 2 menunjukkan perbedaan yang signifikan antara sebelum dan sesudah pembelajaran. Perbedaan tersebut dapat dipahami karena proses pembelajaran menekankan pada proses kegiatan bersama, interaksi, dan kolaborasi yang dipadukan dengan kegiatan praktikum.

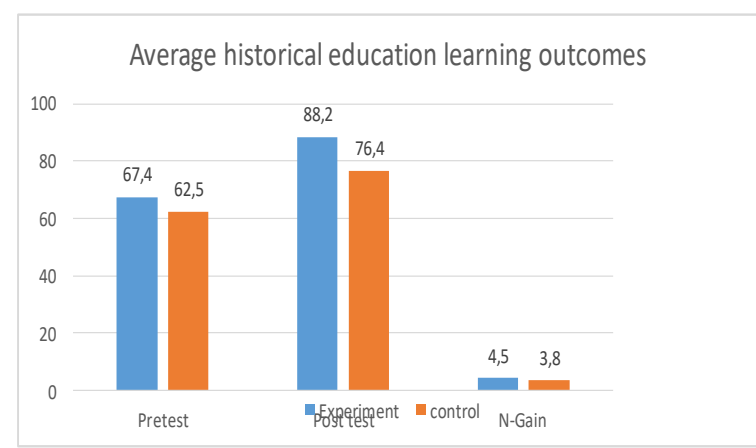

Gambar 1. Perbandingan nilai mean pretest, posttest dan n-gain Modul Pembelajaran Berbasis Multikultural

Multikultural sekaligus
membentuk sekolah untuk
mampu
mendobrak enkapsulasi etnis dan penyekat
soaial budaya lainnya. Selain itu perguruan
tinggi diharapkan dapat mengembangkan
mahasiswa agar menjadi makhluk yang melek-
etnik (ethnic literacy) dan melek kebinekaan
budaya. Kebinekaan budaya yang ada
dilahirkan oleh berbagai aspek kehidupan,
seperti agama, suku, keturunan, kondisi sosial
ekonomi, dan tahapan kekuasaan.


Pengembangan modul sejarah berbasis berbasis multikultural berprinsip integratif, kompak, dan konsisten. Integratif berarti mengintegrasikan pendidikan karakter berbasis multikultural ke dalam seluruh program dan kegiatan di perguruan tinggi. Kompak berarti seluruh komponen pendidikan memiliki sikap dan pandangan yang sama dalam mengimplementasikan pendidikan karakter berbasis multikultural. Konsisten artinya seluruh komponen pendidikan memiliki sikap dan pandangan yang konsisten dalam menerapkan pendidikan karakter berbasis multikultural.

Dosen memiliki peranan yang sangat penting dalam upaya Pengembangan modul sejarah berbasis berbasis multikultural Untuk Meningkatkan Kualitas Pembelajaran Pada Pendidikan Sejarah melalui pengajaran yang responsif perencanaan pembelajaran.

Multikulturalisme serta multietnis membentuk sekolah yang mampu mendobrak enkapsulasi etnis dan persoalan budaya lainnya. Selain itu, perguruan tinggi diharapkan mengembangkan mahasiswanya menjadi melek etnis dan melek keragaman budaya. Keragaman budaya yang ada lahir dari berbagai aspek kehidupan, seperti agama, suku, keturunan, kondisi sosial ekonomi, dan tahapan kekuasaan.

Pengembangan modul pembelajaran berbasis multikultural dengan prinsip integratif, kompak, dan konsisten. Integratif berarti mengintegrasikan pendidikan karakter berbasis multikultural ke dalam semua program dan kegiatan di perguruan tinggi. Compact artinya semua komponen pendidikan mempunyai sikap dan pandangan yang sama dalam melaksanakan pendidikan karakter berbasis multikultural. Konsisten artinya semua komponen pendidikan mempunyai sikap dan pandangan yang konsisten dalam melaksanakan pendidikan karakter berbasis multikultural.

\section{PENUTUP}

Ahli Desain Pembelajaran, ahli desain grafis, dan ahli konten materi pendidikan sejaran menyatakan bahwa modul pembelajaran eksperiensial berbasis kerangka kerja desain pembelajaran integratif layak untuk digunakan dalam pembelajaran Pendidikan Sejarah.

Hasil uji validasi dan uji coba produk pada uji perorangan, kelompok kecil dan lapangan menyatakan bahwa Modul Pendidikan Sejarah sangat bermanfaat untuk digunakan dalam proses pembelajaran dalam rangka perencanaan dan pengembangan pembelajaran, sehingga dapat memberikan peningkatan dalam prestasi hasil belajara mahasiswa.

Hasil penelitian menunjukkan bahwa kualitas pelaksanaan pembelajaran pada uji coba terbatas pada kriteria modul yang dikembangkan sangat baik dan layak digunakan dalam proses pembelajaran dalam pembelajaran pendidikan sejarah. Penilaian Pelaksanaan Pembelajaran dengan Modul Pembelajaran Uji Coba layak digunakan dalam proses pembelajaran Pendidikan Sejarah.

Hasil penelitian ini menunjukkan bahwa penerapan Modul sejarah berbasis berbasis multikultural pada pembelajaran pendidikan sejarah memiliki hasil belajar yang lebih tinggi jika dibandingkan dengan bahan ajar konvensional. Keefektifan Modul sejarah berbasis berbasis multikultural pada pendidikan terhadap hasil belajar digunakan dalam meningkatkan hasil belajar pada mata kuliah pendidikan sejarah.

\section{DAFTAR PUSTAKA}

Anderson, Benedict. (1983). Imagined Communities: Reflections on the Origin and Spread of Nationalism, London: The Thetford Press Ltd. Vanderburg (1985:272)

Arifudin, Iis. (2007). “Urgensi Pendidikan Multikultural di Sekolah", dalam Insania, Vol 12 No. 2, Mei - Agustus 2007, P3M STAIN Purwokerto, h. 4.

Banks, J.A. (1988). Approaches to multicultural curriculum reform. Multicultural Leader, 1(2), 1-3. Diunduh 12 Agustus 2011, dari http://people. $\quad$ ucsc.edu/ marches /PDFs/Approaches\% 20to $\% 20$ Multicultural \%20Reform, \%20Banks.PDF.

Banks, J.A., Cortes, C.E., Gay, G., Garcia, R.L., \& Ochoa, A. (1992). Curriculum guidelines for multicultural education (Rev. ed.), Washington, DC: National Council for the Social Studies.

Hasan,.S.H. (1999). "Pendidikan Sejarah Untuk Membangun Manusia Baru Indonesia”, dalam Mimbar Pendidikan, Nomor 2 Tahun XVIII, Bandung IKIP Bandung, hlm.4-11.

Robinson, James Harvey. (1965). The New History, New York: The Free Press. Burke, 
Saifuddin, Achmad Fedyani. (2006). Reposisi Pandangan mengenai Pancasila: Dari Pluralisme ke Multikulturalisme . Dalam Restorasi Pancasila: Mendamaikan Politik Identitas dan Modernitas. Bogor: Brighten Press.

Saudi Patro. (1997). Masyarakat Agama dan Pluralisme Keagamaan, Jakarta: Paramadina.

Sonia Nieto. (2002). Language, Cultural, and Teaching. Mawah: NJ. Lawrence, h. 29.

Tatang M. Amirin. (2012). " Implementasi Pendekatan Pendidikan Multikultural
Kontekstual Berbasis Kearifan Lokal di Indonesia", dalam Jurnal Pembangunan Pendidikan: Fondasi dan Aplikasi, 1(1) 6 Juni 2012.

Tilaar, H.A.R. (2002). Perubahan Sosial dan Pendidikan; Pengantar Paedagoik Transformatif Untuk Indonesia . Jakarta: Grassindo, h. 15.

Tilaar, H.A.R. (2004). Multikulturalisme: Tantangan-tantangan Global Masa Depan dalam Transformasi Pendidikan Nasional. Jakarta: Grasindo. 